Pengembangan Rekayasa dan Teknologi, Vol 16, No. 1, Juni 2020, pp 23-26

p-ISSN: $1410-9840$ \& e-ISSN: $2580-8850$

http://journals.usm.ac.id/index.php/jprt/index

\title{
PENERAPAN METODE ANALITYCAL NETWORK PROCESS (ANP) SEBAGAI REKOMENDASI APLIKASI PEMBELAJARAN MATEMATIKA BERBASIS ANDROID
}

\author{
Safira Nuraisha ${ }^{1}$, Prind Triajeng Pungkasanti ${ }^{2}$, Yulinda Kusumaningrum ${ }^{3}$ \\ 1,2,3 Sistem Informasi, Universita Semarang \\ $\underline{\text { safira@usm.ac.id }}^{1}$, prind@usm.ac.id ${ }^{2}$, yulinda@usm.ac.id ${ }^{3}$
}

\begin{abstract}
ABSTRAK
Pembelajaran matematika bertujuan membekali mahasiswa untuk dapat berpikir kritis, logis dan praktis, serta bersikap positif dan berjiwa kreatif dalam memecahkan suatu permasalahan dalam berbagai bidang. Hal itu menjadikan matematika merupakan salah satu bidang studi yang dibutuhkan untuk mendukung perkembangan ilmu pengetahuan dan teknologi.

Sekarang ini banyak aplikasi yang digunakan dalam pembelajaran, namun aplikasi tersebut belum bisa membantu mahasiswa dalam memahami mata kuliah matematika. Untuk itu diperlukan sistem pendukung keputusan (SPK) yang dapat membantu dosen dalam menyusun suatu aplikasi pembelajaran matematika. Salah satu metode yang digunakan dalam pengambilan keputusan dalam membuaut aplikasi pembelajaran matematika yaitu metode analytic network process (ANP). Aplikasi dengan metode Analytic Network Process (ANP) adalah suatu metode yang memperhatikan keterkaitan antara strategi objeklif yang satu dengan yang lain. Dengan metode ANP akan membantu dosen dalam menyusun suatu aplikasi pembelajaran matematika berbasis android sesuai dengan harapan mahasiswa.
\end{abstract}

Keywords: Metode ANP, Aplikasi, Pembelajaran Matematika

\section{Pendahuluan}

Teknologi saat ini mengalami perkembangan yang sangat pesat, berbagai penemuan yang mempermudah masyarakat dalam menerima informasi dan membantu pekerjaan sehari-hari. Ponsel yang awal mulanya digunaan hanya sebagai alat komunikasi kini dapat digunakan untuk bekerja, media hiburan, dan banyak hal lainnya. Ponsel cerdas atau yang biasa juga disebut smartphone merupakan temuan baru di bidang teknologi dan komunikasi, perangkat kecil yang merupakan perpaduan antara ponsel dan komputer. Aplikasi yang dikembangkan pada ponsel cerdas harus merupakan apikasi yang bermanfaat, salah satunya untuk pembelajaran. Dalam pengertian yang umum dan sederhana, belajar seringkali diartikan sebagai ativitas untuk memperoeh pengetahuan (Aunurrahman, 2012). Pembelajaran yang semulanya terjadi ketika tatap muka antara dosen dan mahasiswa, dengan pengembangan aplikasi android sebagai media pembelajaran mahasiswa dapat belajar tanpa bertatap muka dengan dosen apabila tidak bisa masuk kuliah. Sehingga mahasiswa tidak ketinggalan materi dan bisa mempelajarinya di luar kampus.

Kemampuan matematika sangat dibutuhkan guna menghadapi era yang semakin kompetitif dalam bidang ilmu pengetahuan dan teknologi. Matematika merupakan salah satu komponen dari serangkaian mata kuliah yang mempunyai peranan penting dalam pendidikan (Sundayana, 2013). Pembelajaran matematika bertujuan membekali mahasiswa untuk dapat berpikir kritis, logis dan praktis, serta bersikap positif dan berjiwa kreatif dalam memecahkan suatu permasalahan dalam berbagai bidang. Hal itu menjadikan matematika merupakan salah satu bidang studi yang dibutuhkan untuk mendukung perkembangan ilmu pengetahuan dan teknologi.

Pengembangan aplikasi berbasis Android sebagai media pembelajaran matematika perlu untuk dikembangkan. Sekarang ini banyak aplikasi yang digunakan dalam pembelajaran, namun aplikasi tersebut belum bisa membantu mahasiswa dalam memahami mata kuliah matematika. Untuk itu diperlukan sistem pendukung keputusan (SPK) yang 
Pengembangan Rekayasa dan Teknologi, Vol 16, No. 1, Juni 2020, pp 23-26

p-ISSN: $1410-9840$ \& e-ISSN: 2580-8850

http://journals.usm.ac.id/index.php/jprt/index

dapat membantu dosen dalam menyusun suatu aplikasi pembelajaran matematika. Salah satu metode yang digunakan dalam pengambilan keputusan dalam membuaut aplikasi pembelajaran matematika yaitu metode analytic network process (ANP). Aplikasi dengan metode Analytic Network Process (ANP) adalah suatu metode yang memperhatikan keterkaitan antara strategi objektif yang satu dengan yang lain. Dengan metode ANP akan membantu dosen dalam menyusun suatu aplikasi pembelajaran matematika berbasis android sesuai dengan harapan mahasiswa. Sehingga aplikasi tersebut bisa membantu mahasiswa dalam mempelajari mata kuliah matematika.

\section{Metode}

Metode penelitian yang digunakan dalam penelitian ini adalah metode penelitian dan pengembangan atau Reasearch and Development (R\&D). Menurut Sugiono (2017) bahwa metode pengembangan merupakan metode penelitian yang digunakan untuk menghasilkan produk tertentu, dan menguji keefektifan produk tersebut.

Desain pengembangan yang akan digunakan dalam penelitian ini adalah ADDIE. Azizah (2016) menggambarkan tahapan pengembangan ADDIE meliputi Analys, Design, Development, Implementation, dan evaluation.

Tahapan penelitian diawali tahapan analisis, dengan menyebarkan kuisioner kepada target, yaitu mahasiswa jurusan Teknologi Informasi yang mengambil mata kuliah logika matematika. Kuisioner ini digunakan sebagai tolak ukur dalam pembuatan aplikasi android pembelajaran matematika, sehingga aplikasi yang dibuat sesuai dengan harapan dari pengguna. Tahap design yaitu menentukan metode yang digunakan. Metode ANP diterapkan untuk mengolah hasil kuisioner dari target. Metode ini diusulkan untuk meningkatkan hasil optimasi dari pengembangan aplikasi android pembelajaran matematika. Selanjutnya penyusunan kerangka aplikasi serta menyusun konten dari aplikasi. Tahapan development dan implementasi merupakan tahap coding dan uji coba sistem kepada target. pada tahapan implementasi, kembali disebarkan kuisioner untuk mengetahui dampak dari penggunaan aplikasi ini terhadap targer. Tahapan yang terakhir, evaluasi, menganalisis serta melakukan perbaikan terhadap kesalahan yang terdapat pada aplikasi.

\section{Hasil dan Pembahasan}

\section{Hirarki ANP}

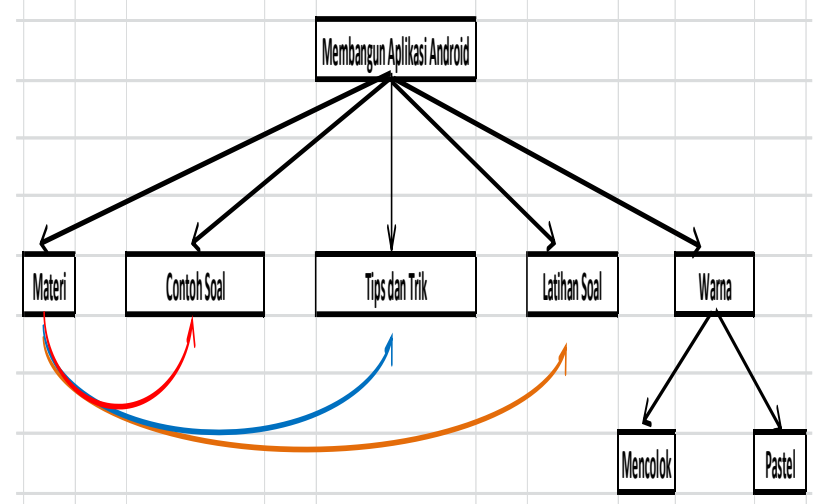

2. Tampilan Pada Aplikasi Berbasis Mobile

a. Tampilan awal aplikasi

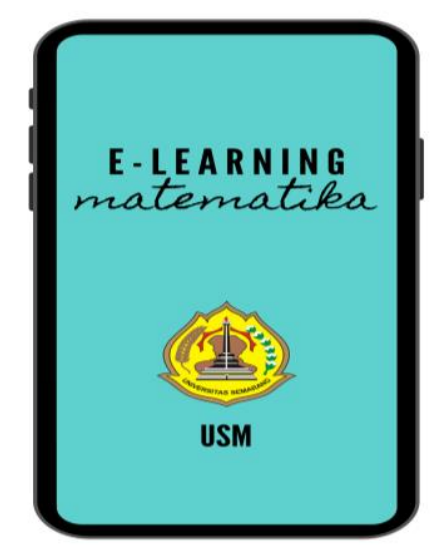

b. Tampilan Menu Utama

Tampilan menu utama ini berisi pilihan sub menu yang meliputi: materi, soal, tips

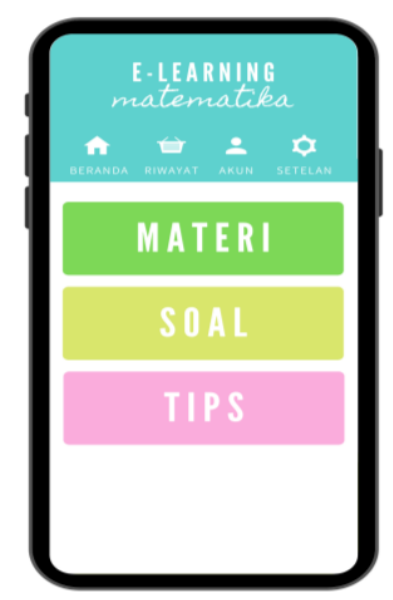


Pengembangan Rekayasa dan Teknologi, Vol 16, No. 1, Juni 2020, pp 23-26

p-ISSN: $1410-9840$ \& e-ISSN: 2580-8850

http://journals.usm.ac.id/index.php/jprt/index

c. Tampilan Menu Materi

Tampilan menu materi ini berisi materi yang terkait dengan matakuliah logika matematika

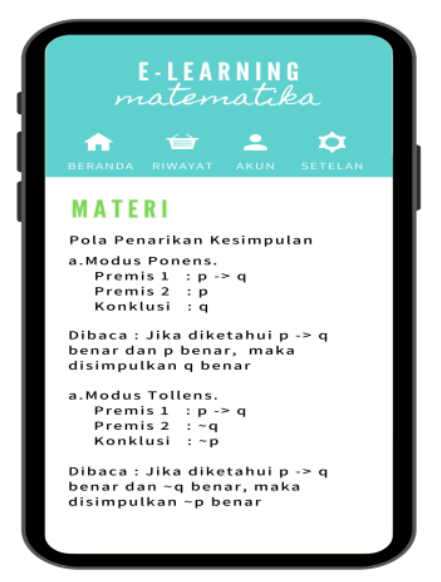

d. Tampilan Menu Soal

Tampilan menu soal ini berisi soal sesuai dengan materi yang dijelaskan pada menu

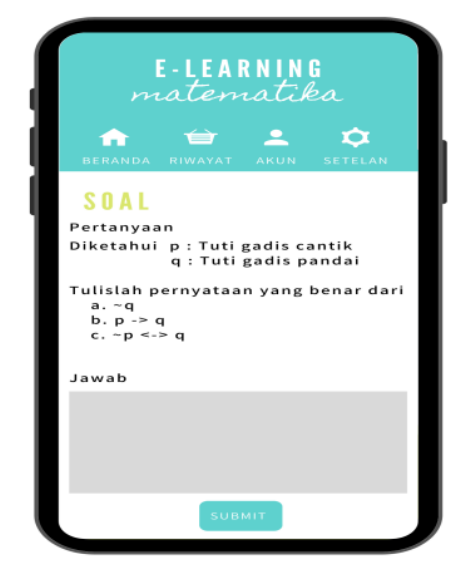

e. Tampilan Menu Tips

Tampilan menu soal ini berisi tips cara mengerjakan soal yang ada pada menu materi

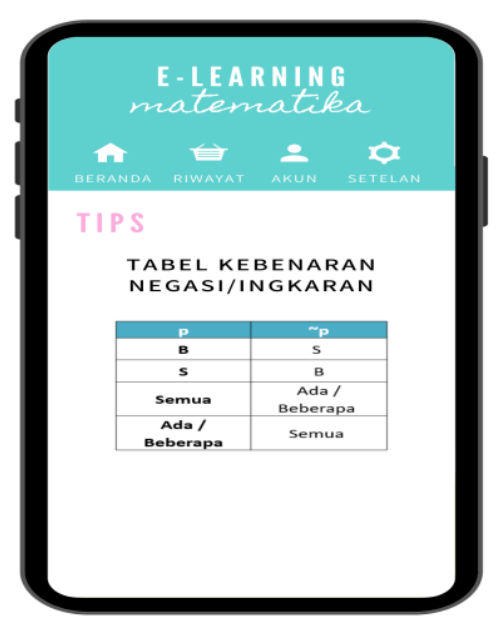

\section{Kesimpulan}

Dari Penelitian ini maka diperoleh beberapa kesimpulan yaitu:

1. Penerapan metode Analitycal Network Process (ANP) sebagai rekomendasi aplikasi berbasis android dapat membantu memudahkan mahasiswa dalam memahami pembelajaran matematika.

2. Respon mahasiswa untuk aplikasi pembelajaran matematika berbasis android sangat baik.

3. Aplikasi ini memberikan tips dan trik dalam memahami matematika sehingga memudahkan mahasiswa dalam mengerjakan soal-soal matematika.

\section{Ucapan Terimakasih}

Peneliti menyampaikan rasa terima kasih yang sebesar-besarnya kepada Lembaga Penelitian dan Pengabdian Kepada Masyarakat Universitas Semarang atas kesempatan yang diberikan sehingga penelitian berlangsung dengan lancar.

\section{Daftar Pustaka}

Abdilah, Maha; Ilhamsyah; Hidayat, Rahmi. 2018. Penerapan Metode Analytic Network Process (ANP) berbasis Android Sebagai Sistem Pendukung Keputusan Dalam Pemilihan Tempat Kos. Jurnal Coding, Rekayasa Sistem Komputer Untan. Volume 06, No. 03 (2018), hal 12-22. Universitas Tanjungpura.

Ally, M. 2009. Mobile learning: transforming the delivery of education and training. Edmonton: AU Press. 
Pengembangan Rekayasa dan Teknologi, Vol 16, No. 1, Juni 2020, pp 23-26

p-ISSN: $1410-9840$ \& e-ISSN: 2580-8850

http://journals.usm.ac.id/index.php/jprt/index

Azizah,Siti. 2016. Pengembangan Media Pembelajaran Matematika Berbasis MUVIZU di kelas 2 Sekolah Dasar. JKPM, Vol.01, No.02, 01 Jun 2016, hlm. 180-192.

Nazruddin Safaat H. 2013. Aplikasi berbasis android. Informatika : Bandung.

Pungkasanti, Prind Triajeng; Handayani, Titis. 2017. Penerapan Analytic Network Process (ANP) pada Sistem Pendukung Keputusan. Jurnal Transformatika, Vol. 14, No. 2.

Setiawan, Arbi Juniar; Darusalam,Ucuk; Andryana, Septi. 2018. Rekayasa Perangkat Lunak Aplikasi Keputusan Multi Kriteria Dengan Algoritma Analytic Network Process Berbasis Android. JSI. Vol. 14. Issue 1. Hlm 33-40.

Hariyanto. 2018. Strategi Penerapan Green Computing Pada Unit Pengelola Sistem Informasi Pembelajaran BerdasarkanMetode Pendekatan Analytic Network Process(ANP). JURIKOM. Vol 5. No. 5. Hlm. 460-470. 